\title{
A Pedagogy for Integrating a Value Congruence and Ethics Connection into Course Work: The Nine Dots Exercise
}

\author{
Dianne Weinstein, Ph.D. ${ }^{1}$ \\ ${ }^{1}$ Cobalt Solutions, Inc., Rockville Centre, New York, U.S.A. \\ Correspondence: Dr. Dianne Weinstein, Cobalt Solutions, Inc., Rockville Centre, New York, U.S.A., Tel: \\ 1-516-763-3178. E-mail: diannew@ cobalt-solutions.com
}

Received: August 6, 2017

Accepted: September 16, 2017

Online Published: September 18, 2017

doi:10.5430/bmr.v6n3p22

URL: https://doi.org/10.5430/bmr.v6n3p22

\begin{abstract}
Value congruence, i.e., the agreement between personal and organizational values, may be viewed as the foundation for one's ethical well-being on-the-job. Yet, the linkage between value congruence and ethics is not soundly addressed in college classrooms. This article describes the pedagogy used to successfully incorporate the value congruence-ethics connection into course work. The author first provides a theoretical introduction as a backdrop for developing the pedagogy including research on value congruence and ethics, the rationale for strengthening the role of "values" in ethics education, and the teaching strategy applied. Thereafter, the author describes steps to teach value congruence and ethics, including learning objectives and an instructional model. The learning objectives and instructional model can be modified to apply within ethics training programs in the workplace.
\end{abstract}

Keywords: Values, Value congruence, Ethics, Ethics education, Experiential exercise

\section{Introduction}

Researchers report that ethics instructional material for college-level courses primarily address two key topics: (1) the identification of ethical issues and (2) the application of moral philosophical frameworks or other decision-making criteria (Baker \& Comer, 2011). Certainly these approaches are germane and quite valuable methods of providing good business ethics education. However, the central focus on ethics identification and decision-making raises an immediate question. Does the focus on these two pedagogical topics position today's college students to "run before they walk" relative to their ethics education? Put another way, does the current-day pedagogical focus jump ahead to topics of higher level thinking before students understand more basic, and arguably, more important concepts relative to ethical well-being in the workplace?

Personal and organizational values are at the heart of potential ethical issues in the workplace, yet the concept of value congruence is rarely discussed in the college classroom. The term value congruence refers to an agreement between individual and organizational values (Chatman, 1991) at work. Value incongruence, on the other hand, is the term used when employee and organizational values are dissimilar (Chatman, 1991; Kalliath, Bluedorn. \& Strube, 1999; O'Reilly, Chatman, \& Caldwell, 1991). When value incongruence occurs, and individual and organizational values are not aligned, conflicts over goals and the means to accomplish goals may take place (Schermerhorn, Jr., Hunt, Osborn, \& Uhl-Bien, 2010) which creates ethical dilemmas (Trevino \& Nelson, 2007).

Thus, the significance of "connecting the dots" between personal values, organizational values, and ethics cannot be understated relative to one's ethical interests at work. This paper describes the pedagogy used by the author to incorporate the value congruence-ethics connection into course work. The author first provides a theoretical introduction as a backdrop for developing this pedagogy including research on value congruence and ethics, the rationale for strengthening the role of "values" in business ethics education, and the teaching strategy applied. Thereafter, the author describes the pedagogy of teaching value congruence and ethics including learning objectives, the underlying instructional model and student feedback on topical issues. The learning objectives and instructional model can be modified for inclusion within ethics training programs at work.

\section{Theoretical Background}

Various streams of research underscore the merits of promoting the value congruence-ethics connection in the classroom, and the teaching methodology to meet this objective. These areas of research are discussed below. 


\subsection{Value Congruence and Ethics Connection: Research}

Ethics has been defined as "the decisions, choices, and actions (behaviors) we make that reflect and enact our values" (Ethics Resource Center, 2012). Various definitions of the term "values" exist including one's convictions as to what is right or wrong (Robbins \& Coulter, 2009), what people would like to achieve in their lives, and the means to achieve life goals (Rokeach, 1973). Regardless of the definition applied, "values" influence how a person behaves (Allport, 1955; Fritzsche \& Oz, 2007; Verplanken \& Holland, 2002; Seevers, 2000; Yukl, 2010) and ethics at work is about one's conduct (Trevino \& Nelson, 2007).

A significant body of research highlights the importance of value congruence and ethics (Ambrose et al.; Edwards \& Cable, 2009; Elango, Paul, Kundu, \& Paudel, 2010; Finnegan, 2000; Krishnan, 2002; Liedtka, 1988; Liedkta, 1989; Posner, Kouzes, \& Schmidt, 1985). In particular, Liedtka (1988) studied the relationship between individual and organization values in relationship to ethics. Study results indicated that managers with more consistent sets of values (i.e., with greater agreement between individual and organizational values) addressed ethical conflicts at a superior level to managers with lower value congruence (i.e., where there was less agreement between individual and organizational values). In addition, the higher the consistency of individual values, the more impactful the values were in affecting ethical dilemma responses.

In a follow-up nationwide study, Posner and Schmidt (1993) demonstrated that managers conveyed more favorable work attitudes and ethical practices of co-workers and their organizations when they were clear about their organizational and personal values. In contrast, managers reported more negative attitudes about their work, co-workers, and organizations, when greater ambiguity about organizational and personal values existed. In addition, this research suggested that clarity about one's individual values may have greater significance regarding attitudes about ethical practices and work than clarity about organizational values. Moreover, when Posner studied this topic in 2010 once more, he affirmed the important connection between personal values, organizational values, and ethics yet again.

Thus, the relevance of the personal values-organizational values-ethics connection cannot be minimized. Value congruence may be viewed as the foundation for one's ethical well-being on-the job. This is a topic that should be highlighted at work.

\subsection{Closing the Gaps between School Curricula, Organizational, and Student Needs}

The path to successful ethics education in support of business needs is unclear (David, David, \& David, 2011; Holland, 2009; Mintzberg \& Goslin, 2002) and the clamor to correct ethical instructional flaws is heightened by the buzz of corporate scandals. Critics of ethics programs bemoan the significant gaps in ethics education at the college level (Lund Dean \& Beggs, 2006). Furthermore, how the topic of ethics is adopted within business school curricula is open to serious debate (Cavaliere, Mulvaney, \& Swerdlow, 2010; Ketcham, 2003; Swanson, 2005). Some educators contend that ethics education should raise awareness of ethical issues while others indicate that analytical skills and moral reasoning should be the primary educational focus (Falkenberg \& Woiceshyn, 2008). Moreover, many ethics programs focus on compliance orientation which "miss[es] the mark of helping students become more ethical because their focus is policy and legality, not morality and ethics" (Lund Dean \& Beggs, 2006, p.16). Certainly, teaching ethics relative to character is in contrast to prevailing approaches that focus on "principles that an agent can apply to situations in business or elsewhere to find the right thing to do" (Hartman, 2006, p.68).

Indeed, much of the ethics education debate rests on the assumption that students grasp the higher level moral reasoning concepts required to successfully study business ethics (Lowry, 2003). However, Weber and Green's research (1991) challenged this assumption, suggesting that higher level ethics educational goals may be ineffective as students' moral reasoning levels are lower than expected. Given the lack of moral reasoning development, Weber and Green suggested that a more concrete understanding of "right and wrong" is warranted as a precursor to higher levels of ethical education. Propitiously, there is growing educator interest in reinforcing and clarifying the values of individuals participating in the business world (Beltramini, Peterson, \& Kozmetsky, 1984). Stewart and Freeman (2011) encourage students to clarify their own values. And Falkenberg and Woiceshyn (2008, p. 213) report an emerging trend where ethical instruction includes "an enhanced awareness of ethical issues, improved reasoning and judgment abilities, stimulation of the moral imagination, and identification and application of the students' own values sets" as components of ethics education. This new direction for ethical instruction opens the door for the design of new educational tools to address the importance of values relative to ethics. 


\subsection{Teaching Strategy: Positioning Value Congruence and Ethics as Personally Relevant to Students for Enhanced Learning}

Most college instructors are not well versed on the topic of ethics (Ketcham, 2003; Swann \& Fisher, 2011) and teaching ethics is a challenging task for educators (Lavine \& Roussin, 2012). Moreover, problems with ethics programs are readily identifiable and questioned by both business professionals and academia alike. Indeed, even students lament the deficiencies of ethics programs based on their firsthand classroom experiences. Student feedback suggests that students do not want business ethics instruction "framed.... in terms of Aristotle" (which this author interprets as being too conceptual in nature and not personally salient to today's students' needs, -- at least from the student perspective.) Instead, students want bottom line "guidance," and to be "told what to expect" relative to ethics at work (Trevino \& Nelson, 2007, p. 2). With these goals in mind, how can instructors position the value congruence-ethics topic to be more relevant and meaningful for students?

Scholars suggest that an important indicator of successful education is student interest in the material (Nicolls, 1979; Jackson, 1968). Individual interest is portrayed as the method by which underlying needs or desires of learners are energized (Alexander et al., 1997). High levels of interest are required to create and maintain a significant intrinsic motivation, i.e., the desire to pursue an activity for its own sake (Deci \& Ryan, 1985) for learning (Hidi, 2000). This is an important form of motivational education (Harackiewicz, Barron \& Elliot, 1998) as motivation and context are essential for learning (Sedig, 2008). While individual interest and intrinsic motivation are different constructs, they both predict like results in that they produce and maintain long-lasting involvement with a subject matter over time (Bye, Pushkar, \& Conway, 2007). Certainly, delivering ethics education that students remember over time is a critical objective for every ethics educator's wish list. So what topic would interest and motivate students to learn and retain information about value congruence and ethics over the long haul?

There has always been a strong interest in career facts by undergraduate students (Kember, Hong, Ho, \& Ho, 2011). Research suggests that "students become more mature, knowledgeable and focused during college" in thinking about career achievement (Pascarella \& Terenzini, 2005). Since students are interested in their career aspirations, it is practical to have students learn about value congruence and ethics by relating these topics to student career goals. The benefits of this approach are many. First, one of the most effective ways to raise a student's motivation to learn is by setting goals. Weinberg (1996) related that "a goal is that which an individual is trying to accomplish; it is the objective or aim of an action" (p.4). From a motivational viewpoint, goal setting directs the attention, effort and persistence of action (Locke, Shaw, Saari, \& Latham, 1981). A goal setting strategy for value congruence-ethics education is particularly germane to Generation Y students, the majority of today's college students, because this generation is goal oriented by nature (Bishop, 2012).

Secondly, aligning career goals with value congruence-ethical course objectives creates a 'win' for both instructors and students alike. Instructors facilitate course work designed to engage student interest and commitment while students experience a real-world application of the value congruence-ethics connection in action. Thirdly, as ethics-related course work is generally delivered to junior and seniors in higher level college courses, course work aligning career aspirations with value congruence and ethics is timely for students who will soon seek full-time employment after graduation. Indeed, students are more likely to retain information when they can immediately put information to use (Snell \& Bohlander, 2010). Fourthly, to some extent, students may be better served and ethics education more relevant if the classroom learning relates to what matters to students personally -- now-- rather than future 'what if' ethical issues (commonly taught by instructors) that students may never encounter. Finally, from a philosophical standpoint, one questions whether educators should take a proactive rather than reactive approach to ethics education. Put differently, if the quest for ethics education is to prepare students for greater ethical thinking at work, wouldn't it make sense to focus on this ethical thinking concept at the beginning of student careers, when they first seek employment, rather than after employment starts [and students are potential already knee-deep in ethical dilemmas]? The Nine Dots Exercise is designed with this rationale and research in mind.

\section{The Nine Dots Value Congruence-Ethics Connection Exercise}

Using this Exercise, educators facilitate a sequence of personally salient experiential exercises which encourages students to learn about the linkage between personal values, organizational values, and ethics relative to employment pursuits.

\subsection{Exercise Learning Objectives}

There are four learning objectives for this Exercise: (1) to help students identify and clarify their personal values, (2) to help students understand the relationship between value congruence and ethics, (3) to learn how to identify 
organizations with values in alignment with a student's personal values, and (4) to identify an organization with values in alignment with personal values. (This organization could potentially serve as a target future employment opportunity for the student.)

\subsection{Target Audience}

The Nine Dots Exercise is designed for application in undergraduate stand-alone ethics courses or discipline-specific courses (e.g., finance, accounting, human resources, marketing, etc.) where ethics is incorporated as a topic within the course. This Exercise may be applied in ground courses and distance learning or hybrid courses with modification. (Refer to the Exercise Variations section below for further discussion of this topic.)

\subsection{Timing}

This Exercise is designed as a precursor activity for higher level ethics instruction on topics such as ethical issue identification and/or ethical decision-making frameworks.

\subsection{The Nine Dots Exercise Model*}

The framework for the Nine Dots Exercise Model is shown in Figure 1. There are nine activities in the Nine Dots Exercise Model.

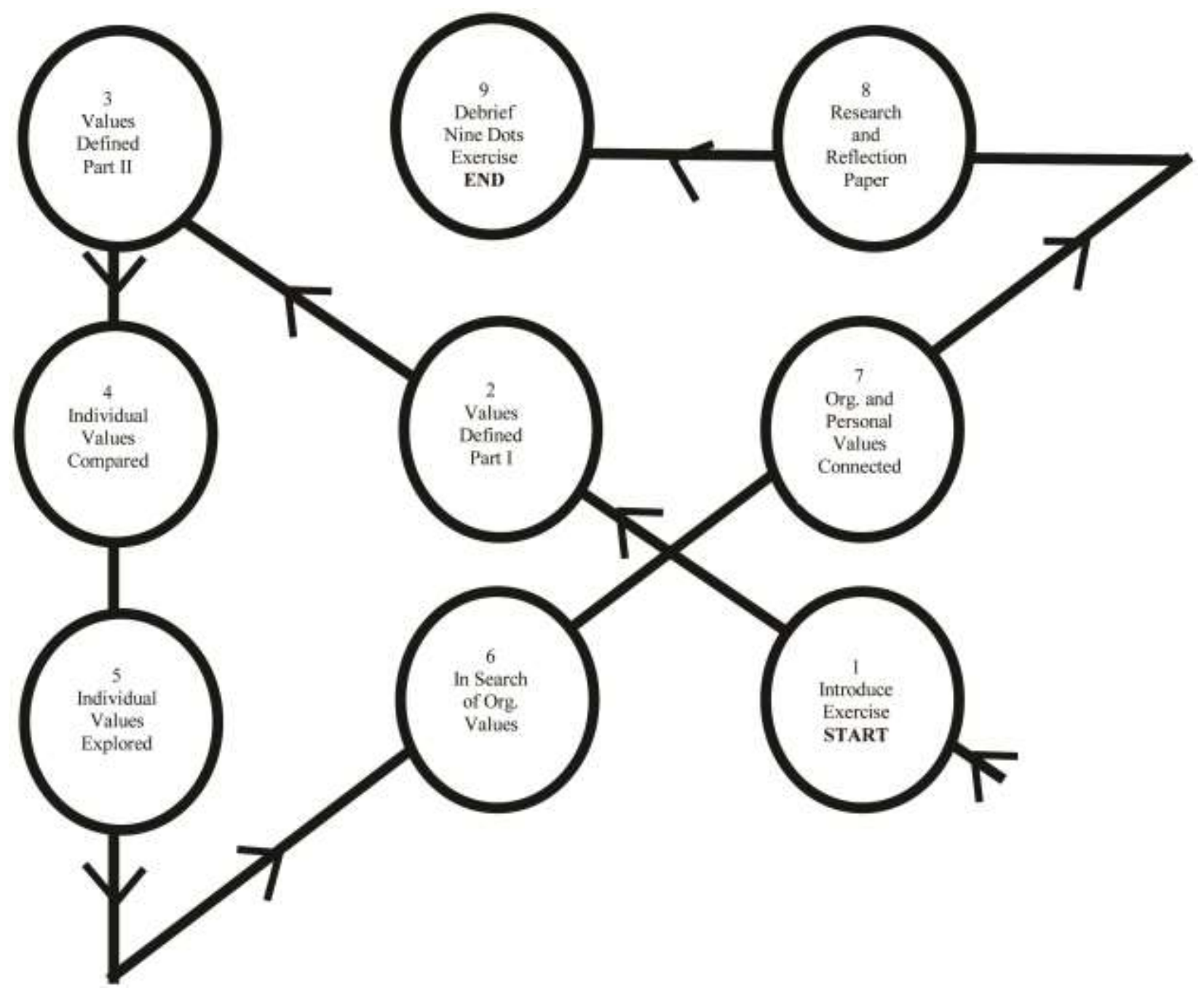

Figure 1. Overview of the Nine Dots Exercise Model

* Various individuals have been credited with developing the original nine dots puzzle including consultant, Michael Vance, puzzle author, Sam Lloyd, and mathematician, Henry Dudeney. 
A description of the supplemental figures and forms supporting each Nine Dots Activity is displayed in Table 1.

Table 1. Outline of the Nine Dots Activities with Figures and Appendices for Application

\begin{tabular}{llc}
\hline Activity & Explanation & Figures/Appendices \\
\hline 1. Introduce Nine Dots Exercise & Overview of Exercise Activities & Figures 1-9 \\
2. Topical Quotes & Presentation enhancement & A \\
3. Values Defined & Activity for completion & B1 \\
(Mix and Match Part I) & Activity answers & B2 \\
4. Valued Defined & Activity for completion & B3 \\
$\quad$ (Mix and Match Part II) & Activity answers & B4 \\
5. Individual Values Compared & Activity for completion & B1, Column A \\
(The "I" is in the Beholder) & & B3, Column A \\
6. Individual Values Explored & Activity for completion & C \\
(Dotting the "I" in Personal Values) & & D \\
7. In Search of Organizational Values & Activity for completion & \\
(General Questions) & Sample questions & E \\
8. In Search of the Organizational and & Sample questions & F \\
Personal Values Connection & Activity for completion & A-F \\
9. Research and Reflection Paper & Assignment instructions & \\
(Connecting Value Congruence and & Students support tools & A-F \\
Ethics to Support Employment Goal) & & G \\
10. Debrief the Nine Dots Exercise & Student support tools & \\
(Lessons Learned) & & Activity for completion \\
11. Research and Reflection Paper & & \\
(ePortfolio version) & &
\end{tabular}

\subsection{Advance Preparation by the Instructor}

Preparatory steps are as follows: (a) review the entire exercise for understanding, (b) determine due dates and course credit, as appropriate, and (c) determine whether optional extra credit assignments will be incorporated within the Exercise (consider extra credit opportunities shown in Activities \#7 and \#9).

\section{Activity 1: Introduce the Nine Dots Exercise to the Class}

At the start of the next class session, distribute 6 stick-on dots [which can be obtained from an office supply store] to each student. This action creates an air of mystery and excitement around the class activities to come which helps to engage students with the course work.

Advise student to draw 9 dots as shown in Figure 2. 


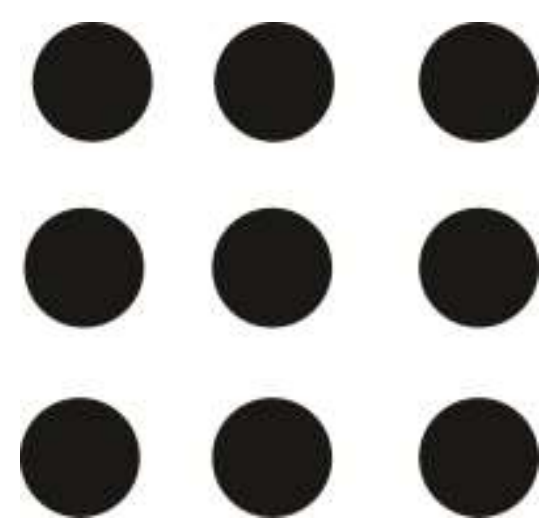

Figure 2. Nine Dots Puzzle

Student Direction: Connect all 9 dots with 4 straight lines....without taking the pen off of the paper. Thereafter, ask students to describe how they individually completed the Activity. Display the Nine Dots Activity Answer Key (Figure 3) on the board or overhead.

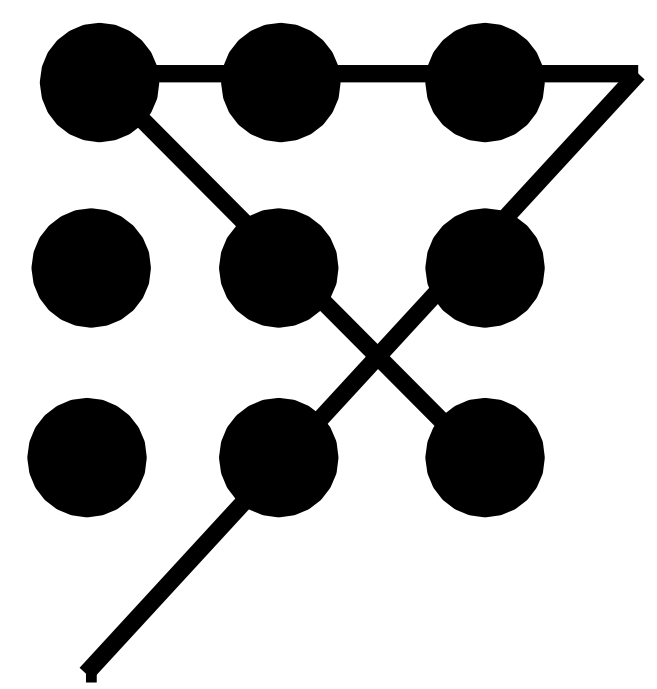

Figure 3. Nine Dots Puzzle Answer Key

Direction: Explain that many people forget to think "outside the box" boundaries, or norms, to complete this activity. The concept of "thinking inside-the box" infers that people think using ideas that are the standard and not using ideas that are novel or new. Creative thinking recognizes and discards the accepted "in-the-box" approach to addressing problems and develops new ideas "outside-of-the-box" instead. Relate: The class will use an "outside-the-box" approach to start a new class topic: Ethics. Ethics has become a very important topic in business. (Instructors may wish to provide examples of why ethics is important in business, in general, and/or relative to the course specific discipline (i.e. finance, accounting, human resources, marketing, etc.).

Lead a discussion on the definition of the terms "ethics" and "values." Post basic definitions on the board or overhead to reinforce key points: (a) ethics - the decisions, choices, and actions (behaviors) a person makes relative to his or her job that reflects and enacts personal values (Ethics Resource Center, 2012), and (b) values - the worth, importance, or usefulness of something to somebody. Personal values are anything a person holds in high esteem. Values are what an individual believes to be important and desirable. Some scholars define values as what is "right and wrong" (Robbins \& Coulter, 2009), which influences a person's behavior, i.e. how you act. Other definitions of 
"values" include what people would like to achieve in their lives, and the means for achieving life goals (Rokeach, 1973). Post Figure 4.

\section{Personal Values}

Figure 4. Connection between Personal Values and Ethics

Direction: Read the statement by noted business scholar, John Schermerhorn, Jr. (2010, p. 91) and reinforce the connection between personal values and ethics as shown in Figure 4.

"Most ethical problems in the workplace arise when people are asked to do, or find they are about to do, something that violates their personal beliefs. For some, if the act is legal, they proceed with confidence. For others, the ethical test goes beyond the legality of the act alone. The ethical question extends to personal values the underlying beliefs and attitudes that help determine individual value" (Schermerhorn, 2012, p. 91.)

Post Figure 5. Relate: Organizational values, convey the values that organizations and organizational members deem to be important (Hitt, 1988). These values reflect what the organization stands for and what it believes in, and they create an environment that influences employee behavior ethically or unethically (Robbins \& Coulter, 2009). Ask: How do organizational values relate to ethics? A lively discussion will likely ensue. For the most part, the class will probably agree that organizational values can impact one's ethics on-the-job.

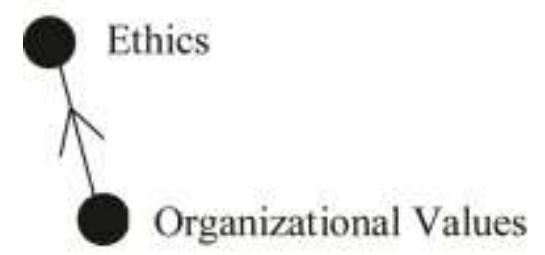

Figure 5. Connection Between Organizational Values and Ethics

Direction: Ask students if they would prefer to work for an organization where their personal values are also valued by the employer or would it be acceptable to work for an organization with values different than student's personal values. This question typically leads to another lively discussion. Student responses vary, however, for the most part, students prefer to work for organizations with values in alignment with their own personal values. Reinforce the point that personal values and organizational values provide the foundation for ethical practices at work. Post Figure 6.

\section{Personal Values}

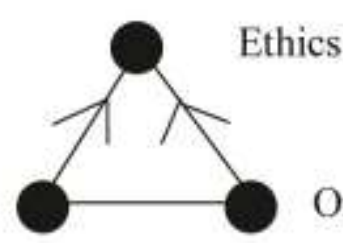

Organizational Values

Figure 6. Connection Between Personal Values, Organizational Values and Ethics

Relate: Value congruence is a term that refers to the agreement of one's personal values and the values of the organization they work for (Chatam, 1991). Indicate that a strong connection between personal values, organizational values, and ethics supports greater individual well-being at work relative to ethics. Post Figure 7. 


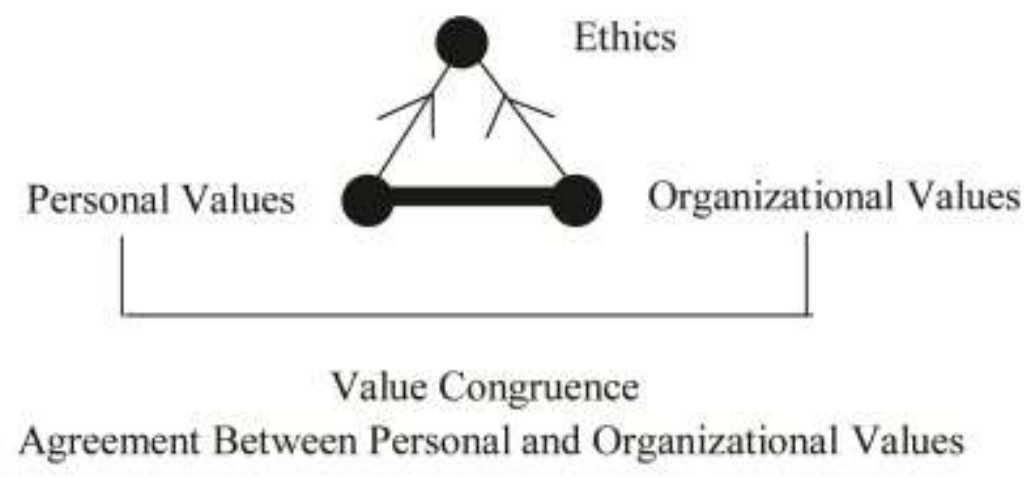

Figure 7. The Connection Between Value Congruence and Ethics

Relate: While value congruence occurs when there is alignment between one's personal values and organizational values, value incongruence occurs when there is a lack of agreement between one's personal values and organizational values (Chatman, 1991; Kalliath et al., 1999; O'Reilly et al., 1991). When value incongruence occurs, and individual and organizational values are not aligned, conflicts over work goals and the means to accomplish goals may take place (Schermerhorn, Jr., Hunt, Osborn, \& Uhl-Bien, 2010) which creates ethical dilemmas (Trevino $\&$ Nelson, 2007). Instructors should provide illustrations of these points.

Post Figure 8. Define ethical dilemma. Point to the arrow signifying a gap between personal and organizational values. Ensure that students understand that a gap between personal and organizational values can lead to ethical issues. Note: The instructor may choose to relate various discipline-specific examples to reinforce this point. Indicate: The misalignment of personal and organizational values is often the starting point for ethical dilemmas at work. Therefore, the significance of aligning one's personal values and organizational values and ethics cannot be understated relative to one's ethical well-being at work.

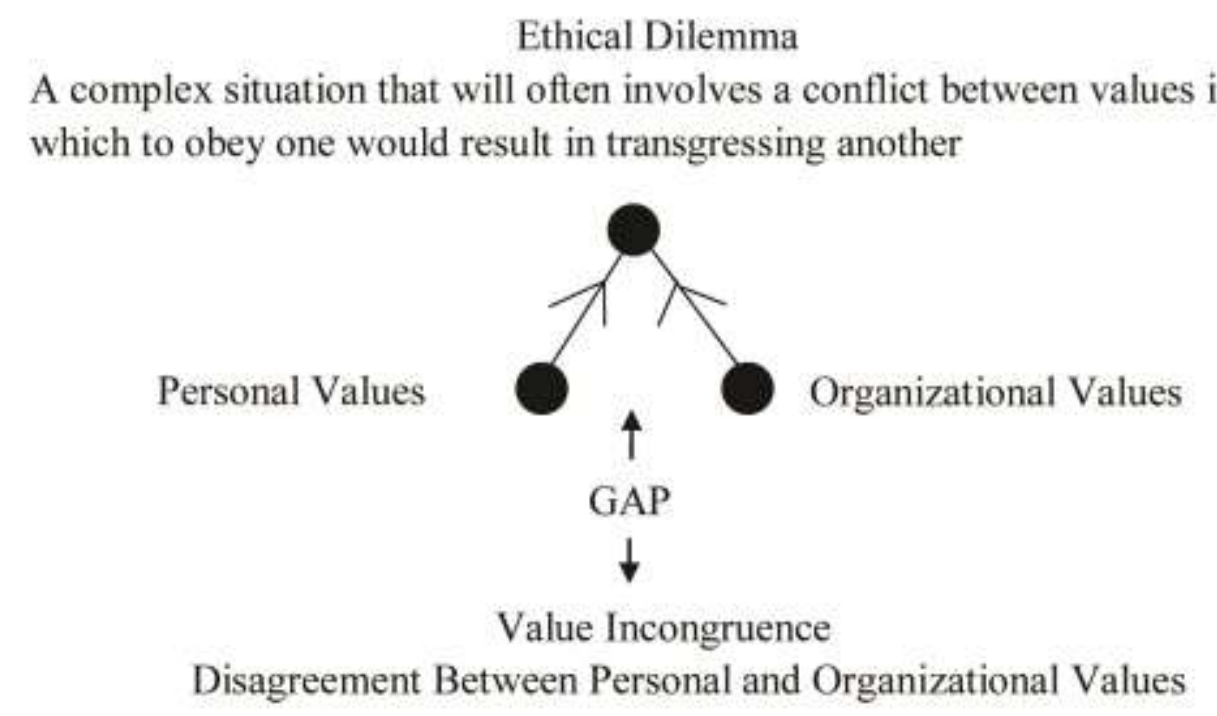

Figure 8. The Relationship Between Ethical Dilemma and Value Incongruence

Post Figure 9. Relate: As juniors and seniors at this college (or university), many students will soon graduate from the school. A goal to pursue employment that supports value congruence and ethics is a positive employment objective for students. 


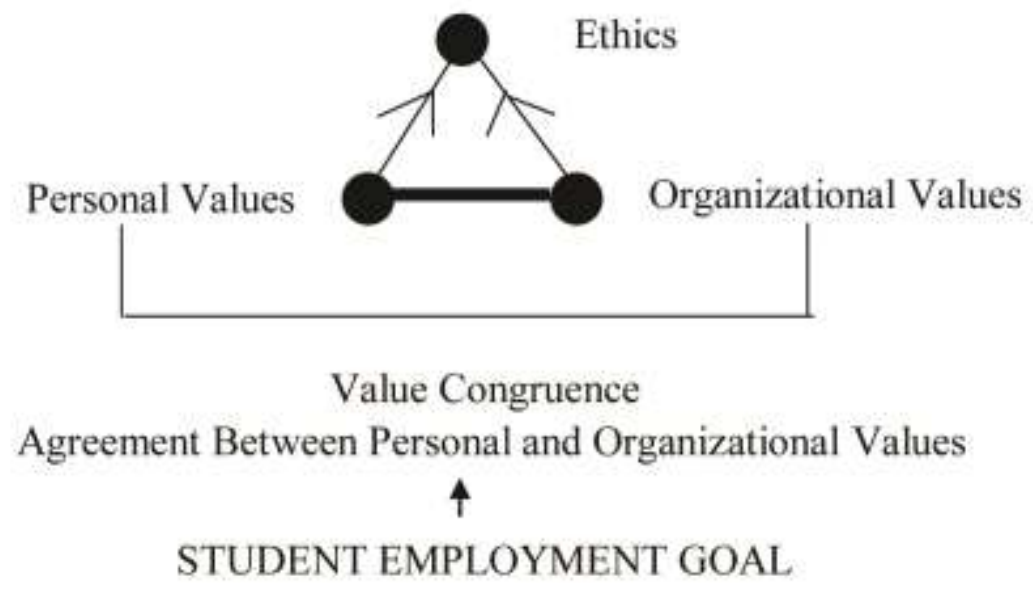

Figure 9. Connecting Value Congruence, Ethics, and a Student Employment Goal

Post the Nine Dots Exercise Model (Figure 1). Relate: Over the next few days, the class will complete The Nine Dots Exercise, a series of real-world experiential activities that will help students better understand the vital connection between their personal values, organizational values, and ethical success on-the-job -- in relation to their post graduation employment goal. Describe each step of the integrated Nine Dots Exercise Model.

Activity \#2: Individual Values Defined - The Mix and Match Activity Part

Distribute the Mix and Match Activity- Part I (Appendix B1). Review the instructions to complete the activity with the class. Indicate that the term "values" may be defined in different ways and the list distributed defines values as what people would like to achieve in their lives. Remind students that values are based on one's personal convictions and so there are no "right" or "wrong" values. Encourage students to add other values of personal importance in Section D of the Form. After students conclude the Activity, review Mix and Match Activity-Part I Answers (Appendix B2) to ensure that students understand the definitions of each value provided. If students added supplemental values to the list of values, discuss these values at this time.

\section{Activity \#3: Individual Values Defined - The Mix and Match Activity Part II}

Distribute the Mix and Match Activity-Part II (Appendix B3) and introduce the activity. Review the instructions to complete the activity with the class. Indicate that the term "values" may be defined in different ways and this list presents the term "values" as the means to attain one's life goals. Indicate that this list does not include all possible values. Encourage students to add values to the list in Section D of the Form. Remind students there are no right and wrong values.

After the activity is completed by students, review the answers to the Mix and Match Activity-Part II (Appendix B4) to ensure that students understand each of the definitions provided. Values added by students should be discussed with the class.

\section{Activity \#4: Individual Values Compared - The "I" is in the Beholder}

Post the poster-size list of the personal values utilized in the Mix and Match Part I activity for student viewing (Appendix B1, Column A). Write in personal values added by students in class. One-by-one, students then post the stick-on dots (which were previously distributed) next to their individual top 3 values. This "dot" approach adds a sense of drama and fun to the Activity. Repeat the same process on a second poster-size list (Appendix B3, Column A).

Discuss the outcome of the dot placement on the posters, making sure that student selections are validated (i.e., there are no "right" or "wrong"). The following are common student responses to this Activity: "People have different values." "People rank the importance of values differently." "While I didn't expect students to agree on the priority of the values, I did expect students to at least agree on the major values. That didn't happen." Note: If students do not raise the above points, the instructor should raise these topics for discussion. Indicate that when people have different values, conflicts may arise. (The instructor is encouraged to provide illustrations of situations where valuing different values may lead to conflict and ethical dilemmas.) As noted earlier, conflicts in values can lead to ethical dilemmas. 


\section{Activity \#5: Individual Values Explored - "Dotting the 'I" in Personal Values}

Distribute the Individual Values Explored Form (Appendix C). Note that college is a stage in one's life where people may first be coming to terms with their values. Students may yet be unclear about their value priorities... and that is acceptable. Indicate that students should again consider their top 3 values per list.

Students then enter their top 6 values and describe why each value selected is individually important to them on the Form. The instructor should provide examples of justifications for selecting top values to ensure that students understand the focus of the Activity. For example, selecting "a world of beauty" may be important for someone who grew up in a household where the environment is an important issue.

Use the following question as a starting point to debrief the activity: What have we learned from this exercise? Common student responses include: "Students value different values." "Since values are 'personal' people will have different reasons for valuing values." Note: If students do not raise these points, the instructor should raise these topics for discussion. Also, reinforce the point that people have different values and people have different reasons for valuing specific values. Ask: How could this fact impact how employees work together toward work goals? Possible responses: "People's personal values can impact business decisions." "It may be difficult to encourage groups of people to work together who have different values." Remind students that when people have different values, conflicts and ethical dilemmas may arise. (The instructor is encouraged to provide illustrations of situations where valuing different values may lead to conflict and ethical dilemmas.)

\section{Activity \#6: In Search of Organizational Values}

Relate: Organizational values, that is values promoted by organizations, help to define the norms which guide the behaviors of people within organizations. Indicate that values may be identified by what is communicated by an organization and/or by the behaviors or actions of organizational members.

Distribute the listing of general questions used to identify organizational values (Appendix D). Discuss these general questions as examples of methods to identify organization values using the college or university as the target organization for evaluation. Explain that answers to these questions may be found on various internal organizational resources such as the organization's website, sales literature, recruitment literature, promotional material, advertisements and other material provided by the organization, etc. Indicate that information relative to these questions may also be found via external sources such as: articles, blogs, etc. about the organization or media forms (e.g. television, radio, etc.), trade associations, social media websites, government information about the organization, information related by current and former employees about the organization, etc. Ask students to suggest additional sources. Present examples of how the college's values are reflected in external information.

\section{Activity \#7: In Search of an Organizational and Personal Values Connection}

Distribute the overview of sample questions to further explore organizational values that relate to personal values (Appendix E). Review the questions shown and discuss examples of how these questions can help assess patterns of organizational values. Assign the following homework assignment which is due the next class. Students should use these questions to relate their 6 top individual values and the organizational values of the school. Based on this analysis, students should come to class prepared to describe whether the school would be a good target employer value-wise (i.e., the school's values align with the student's personal values) or not, and why. (Note: The author sometimes assigns this assignment as an extra credit assignment to encourage greater class completion of the Activity.)

Debrief the activity when the class reconvenes at the next class session. Student reactions to this activity typically vary. Common student reactions are noted: "Although aligning organizational and personal values is not a "black and white" process, I was able to get a feel for whether the school would be a good employer for me to work for." "I wasn't able to identify all of my top values at the school, but I saw that the school promoted some of the values that are important to me." Note: Completion of this Activity may stimulate student thinking about other ways that organizations express their values. Discussion of these additional methods may be warranted.

Activity \#8: Research and Reflection Paper - Connecting Value Congruence, Ethics, and the Student's Employment Goal

Direction: As we have discussed, it is in a student's best interest to recognize the relationship between value congruence and ethics, and to be able to identify organizations with values that align with their personal values. Post Figure 1. In Activity \#8 of the Nine Dots Exercise, students will complete a research and reflection paper that explores the connection between value congruence, ethics and the student's employment goal after graduation. 
Review the Instructions for researching and writing this paper (Appendix F) including the grading guidelines for the assignment. Recap the objectives of Activities \#1-\#7 and remind students to use Activities \#1-\#7 to support their work when completing the paper.

\section{Activity \#9: Debriefing the Nine Dots Exercise: Lessons Learned (after papers are graded)}

Post Figure 1. Review the nine steps of the Nine Dots Exercise. Then lead a recap discussion on the following topics: (1) people's values will differ, (2) organizational values will differ, (3) the definitions of value congruence and value incongruence, and (4) the importance of value congruence at work. Indicate that ethics has become a big issue at work. Ask: What did students learn when investigating value congruence and ethics in behalf of this writing project? (The research generally indicates that value congruence leads to greater ethical well-being at work.) Ask students to describe the organizations that they identified for future potential employment and the reasons they selected these organizations for their papers (i.e., reasons will likely relate to personal values, organizational values and ethics.) Ask students who completed the optional extra credit assignment to explain the relationship between value congruence and ethics in their fields or disciplines. Ask these students to indicate if and how the organizations they selected for future potential employment pursuits support value congruence and ethics in their chosen fields.

Discuss "lessons learned" from the Nine Dots Exercise. Student responses may vary, however, common student responses include: "There is a connection between personal values, values and my ethics at work." "This Exercise is important because it focuses on helping students professionally succeed at work, i.e., it's a real-world exercise." "After completing this Exercise, I see that I can use the Nine Dots Exercise to my advantage. I can look for jobs that better support my personal values. "The class completed this Exercise at the right time, just before students graduate. Students can use this material for their upcoming job searches." "Although we used the material for a job search after graduation, the Nine Dots process can be applied for future job searches." Note: If students do not raise these points, the instructor should raise these topics for discussion.

\section{Exercise Variations for Distance Learning Courses and/or Hybrid Courses}

This exercise was originally designed for application in a ground course. However, the exercise can be modified to work well in hybrid or distance learning courses. In a hybrid or distance learning environment, exercises are posted on electronic online management learning systems for completion. The author typically uses Discussion Forums to facilitate the various Activities, with the exception of Activity \#8, the paper. The Individual Paper can be submitted either as an individual paper or as an ePortfolio presentation. (An e-portfolio, also known as an electronic portfolio or digital portfolio, is an electronic venue to collect student work, achievements, and/or other credentials that a student posts on a website. These electronic portfolios are often used for job search pursuits, course reflection and/or presentation purposes.) An overview of instructions for an ePortfolio presentation project is shown in Appendix $\mathrm{G}$ as a convenience to instructors wishing to use an ePortfolio format. If an ePortfolio format is selected, it is recommended that the instructor provide a template for students to complete as part of the ePortfolio assignment. The instructor should also provide students with Grading Guidelines for the ePortfolio format.

\section{Exercise Observations and Concluding Remarks}

To be sure, there is a gap in ethics education (Lund Dean \& Beggs, 2006) and critics of ethics programs continuously question the appropriateness of classroom activities for ethical instruction. While there is no cookie-cutter approach to sound ethics instruction to-date, using the Nine Dots Exercise to raise student awareness of the value congruence and ethical thinking relationship creates a strong foundation for future ethics education.

The Nine Dots Exercise provides a systematic approach to understanding the critical connection between personal values, organizational values, and ethics, while providing ways to promote value congruence and ethical well-being when seeking employment. The Exercise has been successfully administered in many business courses with favorable reviews by both instructors and course participants alike. In addition to the positive Exercise comments shared by students (above), the author shares some of the Exercise characteristics that she has witnessed throughout the many years of delivering this material.

In sum, the Exercise is relevant, beneficial, memorable, and practical. Lively class discussions throughout the Exercise process create a convincing case for students to acknowledge the important personal values-organizational values-ethics connection for greater on-the-job success. The topic of values and ethics becomes more meaningful to students as they learn how to consider values and ethics relative to their own employment pursuits. Furthermore, the sequential flow of the Exercise piques student interest and fully engages students in the process. The activities validate student experiences and views, making it easy for students to remember, work with, and build upon key points. Moreover, the hands-on activities create a sense of urgency to complete the Exercise goal of linking value 
congruence and ethics to a job search. Furthermore, students find the course work to be easy-to-apply, and enjoy completing a real-world Exercise that supports ethical and career success.

On a related note, this Exercise can be adapted for application in work settings. Activities can be presented as training activities within learning modules. The author recommends this approach based on the delivery of successful ethics training programs.

\section{References}

Alexander, P. A., Murphy, P. K., Woods, B .S., Duhon, K. E. \& Parker, D. (1997). College Instruction and Concomitant Changes in Students' Knowledge, Interest, and Strategy Use: A Study of Domain Learning, Contemporary Educational Psychology. 22, 125-146. https://doi.org/10.1006/ceps.1997.0927

Allport, G.W. (1955). Becoming: Basic Considerations for a Psychology of Personality. New Haven, CT: Yale University Press. https://doi.org/10.2307/2022446

Ambrose, M. L., Arnaud, A. \& Schminke, M. (2008). Individual Moral Development and Ethical Climate: The Influence of Person-Organizational Fit on Job Attitudes. Journal of Business Ethics, 77, 323-333. https://doi.org/10.1007/s10551-007-9352-1

Baker, S. D. \& Comer, D .R. (2011). Business Ethics Everywhere: An Experiential Exercise to Develop Students' Ability to Identify and Respond to Ethical Issues in Business. Journal of Management Education, 36, 95-25. https://doi.org/10.1177/1052562911408071

Beltramini, R. F., Peterson, R. A. \& Kozmetsky, G. (1984). Concerns of College Students Regarding Business Ethics. Journal of Business Ethics, 3, 195-200. https://doi.org/10.1007/978-94-007-4126-3_19

Bishop, J. (2003). Goal Setting for Students, St. Louis, MO: Accent on Success.

Bye, D., Pushkar, D. \& Conway, M. (2007). Motivation, Interest, and Positive Affect in Tradition and Traditional Undergraduate Students. Adult Education Quarterly, 57, 141-158. https://doi.org/10.1177/0741713606294235

Cavaliere, F.J., Mulvaney, T.P. \& Swerdlow, M.R. (2010).. Teaching Business Ethics After the Financial Meltdown: Is It Time for Ethics with A Sermon, Education. 131, 3-7.

Chatman, J. (1991). Matching People and Organizations: Selection and Socialization in Public Accounting Firms. Administrative Science Quarterly, 36, 459-484. https://doi.org/10.2307/2393204

David, R.R., David, M.E. \& David, F.R. (2011). What are Business Schools Doing for Business Today? Business Horizons, 54, 51-62. https://doi.org/10.1016/j.bushor.2010.09.001

Deci, E. L. \& Ryan, R. M. (1985. Intrinsic Motivation and Self-Determination in Human Behavior, New York, NY: Plenum. https://doi.org/10.1007/978-1-4899-2271-7

Edwards, J. R. \& Cable, D. M. (2009). The Value of Value Congruence. Journal of Applied Psychology, 94, 654-677. https://doi.org/10.1037/a0014891

Elango, B., Paul, K., Kundu, S.K. \& Paudel, S.K. (2010). Organizational Ethics, Individual Ethics, and Ethical Intentions in International Decision-Making. Journal of Business Ethics, 97, 543-561. https://doi.org/10.1007/s10551-010-0524-z

Ethics Resource Center. Glossary, Retrieved July 14, 2012, from http://www.ethics.org/resource/ethics-glossary Falkenberg, L. and Woiceshyn, J. (2008). Enhancing Business Ethics: Using Cases to Teach Moral Reasoning. Journal of Business Ethics, 79, 213-217. https://doi.org/10.1007/s10551-007-9381-9

Finnegan, J.E. (2000). The Impact of Person and Organizational Values on Organizational Commitment. Journal of Occupational and Organizational Psychology, 73, 149-169. https://doi.org/10.1348/096317900166958

Fritzsche, D.J. \& Oz, O. (2007). Personal Values' Influence on the Ethical Dimension of Decision-Making. Journal of Business Ethics, 75, 335-343. https://doi.org/10.1007/s10551-006-9256-5

Harackiewicz, J.M. \& Barron, K.E. (1998). Rethinking Achievement Goals: When Are They Adaptive for College Students and Why?. Educational Psychologist, 33, 1-21. https://doi.org/10.1207/s15326985ep3301_1

Hartman, E.M. (2006). Can We Teach Character? An Aristotelian Answer. Academy of Management Learning \& Education, 5, 68-81. https://doi.org/10.5465/amle.2006.20388386

Hemingway, C.A. \& Maclagan, P.W. (2004). Managers' Personal Values as Drivers of Corporate Social Responsibility. Journal of Business Ethics, 50, 33-44. https://doi.org/10.1023/b:busi.0000020964.80208.c9 
Hidi, S. (2000). An Interest Researcher's Perspective: The Effects of Extrinsic and Intrinsic Factors on Motivation. In C. Sansone and J.M. Harackiewicz (Eds.), Intrinsic and Extrinsic Motivation: The Search for Optimal Motivation and Performance, (pp. 373-404), San Diego, CA: Academic Press. https://doi.org/10.1016/b978-012619070-0/50033-7

Hitt, W.D. (1988). The Leader-Manager: Guidelines for Action, Columbus, OH: Batelle Press.

Holland, K. (2009). Is It Time to Retrain B-Schools?. The New York Times, Retrieved from http://www.nytimes.com/2009/03/15/business/15school.html.

Jackson, P. W. (1968). Life in Classrooms. New York, NY: Holt, Rinehart \& Winston.

Johnston, C. S. (1995), The Rokeach Value Survey: Underlying Structure and Multidimensional Scaling. The Journal of Psychology, 129,. 583-597. https://doi.org/10.1080/00223980.1995.9914930

Kalliath, T. J., Bluedorn, A. C. and Strube, M. J. (1999). A Test of Value Congruence Effects. Journal of Organizational Behavior, $20, \quad 1175-1198$. https://doi.org/10.1002/(sici)1099-1379(199912)20:7<1175::aid-job960>3.0.co;2-5

Kember, D., Hong, C., Ho, A. and Ho, A. (2011). More Can Mean Less Motivation: Applying a Motivational Orientation Framework to the Expanded Entry into Higher Education in Hong Kong. Studies in Higher Education, 36,. 209-225. https://doi.org/10.1080/03075070903514062

Ketcham, A. F. (2003). Variations On the Ethics Component of The AACSB Accreditation Process. Journal of the Academy of Business Education, Retrieved January 8, 2010, from https://abe.villanova.edu/proc2003/ketcham.pdf.

Krishnan, V. R. (2002). Transformational Leadership and Value System Congruence. International Journal of Value-Based Management, 15,. 19-33.

Lavine, M.H. and Roussin, C.J. (2012).From Idea to Action: Promoting Responsible Management Education Through a Semester-Long Academic Integrity Learning Project. Journal of Management Education, 36, 428- 55. https://doi.org/10.1177/1052562911428602

Liedtka, J.M. (1988). Managerial Values and Corporate Decision-Making: An Analysis of Value Congruence. Dissertation, Boston University, MA AAT88006763.

Liedtka, J.M. (1989). Value Congruence: The Interplay of Individual and Organizational Value Systems. Journal of Business Ethics, 8, 805-815. https://doi.org/10.1007/bf00383780

Locke, E.A.,Shaw, K.N., Saari, L.M. and Latham, G.P. (1981). Goal Setting and Task Performance: 1969-1980". Psychological Bulletin, 90, 125-152. https://doi.org/10.1037//0033-2909.90.1.125

Lowry, D. (2003). An Investigation of Student Moral Awareness and Associated Factors in Two Cohorts of an Undergraduate Business Degree in a British University: Implications for Business Ethics Curriculum Design. Journal of Business Ethics, 48, 7-19. https://doi.org/10.1023/b:busi.0000004383.81450.96

Lund Dean, K., and Beggs, J. (2006).University Professors and Teaching Ethics: Conceptualizations and Expectations. Journal of Management Education, 30, 15-44. https://doi.org/10.1177/1052562905280839

Mintzberg, H. and Gosling, J. H. (2002). Reality Programming for MBAs, Strategy and Business, Retrieved from https://doi.org/10.1007/978-3-322-91041-7_6

Nicholls, J.G. (1979). Quality and Equality in Intellectual Development. American Psychologist, 34, 1071- 1084. https://doi.org/10.1037/0003-066x.34.11.1071

O'Reilly, C. A., Chatman, J. and Caldwell, D.F. (1991). People and Organizational Culture: A Profile Comparison Approach to Assessing Person-Organizational Fit. Academy of Management Journal, 34, 487-516. https://doi.org/10.2307/256404

Pascarella, E.T. and Terenzini, P.T. (2005). How College Affects Students, San Francisco, CA: Jossey-Bass. https://doi.org/10.1353/csd.2006.0060

Posner, B.Z (2010). Another Look at the Impact of Personal and Organizational Values Congruency. Journal of Business Ethics, 97, 535-541. https://doi.org/10.1007/s10551-010-0530-1

Posner, B. Z., Kouzes, J. M. and Schmidt, W.H. (1985). Shared Values Make a Difference: An Empirical Test of Corporate Culture. Human Resource Management, 24, 293-309. https://doi.org/10.1002/hrm.3930240305 
Posner, B .Z. and Schmidt, W. H. (1993). Values Congruence and Differences Between the Interplay of Personal and Organizational Values Systems. Journal of Business Ethics, 12, 341-347. https://doi.org/10.1007/bf00882023

Robbins, S. P. and Coulter, M. (2009). Management, (10 ${ }^{\text {th }}$ ed.), Upper Saddle River, NJ: Pearson Prentice Hall. https://doi.org/10.1016/j.tourman.2008.11.001

Rokeach, M. (1973). The Nature of Human Values, New York, NY: Free Press. https://doi.org/10.1093/sw/19.6.758

Schermerhorn, J. R., Jr., Hunt, J. G., Osborn, R.N. and Uhl-Bien, M. (2010). Organizational Behavior, (1 ${ }^{\text {th }}$ ed.), Hoboken, NJ: John Wiley \& Sons.

Sedig, K., (2008). From Play to Thoughtful Learning: A Design Strategy to Engage Children With Mathematical Representations. Journal of Computers in Mathematics and Science Teaching, 27, . 65-101.

Seevers, B.S. (2000). Identifying and Clarifying Organizational Values. Journal of Agricultural Education, 41, 70-79.

Snell, S. and Bohlander, G. (2010). Managing Human Resources, (16th ed.), Mason,GA: South- Western Cengage Learning.

Stewart, L. A and Freeman, R. E. (2011). Assessing Business Ethics Education: Assessment From Where and For What? In R. A. Giacalone and C.L. Jurkiewicz (Eds.). Toward Assessing Business Ethics Education, (pp. 49-56), Charlotte, NC: Information Age Publishing, Inc.

Swann, D. L. and Fisher, D. G. (2011). Assessing Business Ethics Education: Starting the Conversation in Earnest, In R. A. Giacalone and C.L. Jurkiewicz (Eds.). Toward Assessing Business Ethics Education, (pp. 1-12), Charlotte, NC: Information Age Publishing, Inc.

Swanson, D.L. (2005). Business Ethics Education at Bay: Addressing a Crisis of Legitimacy. Issues in Accounting Education, 20, 247-253. https://doi.org/10.2308/iace.2005.20.3.247

Trevino, L.K. and Nelson, K.A. (2007). Managing Business Ethics: Straight Talk About How To Do It Right, (4th ed) Hoboken: N J. https://doi.org/10.3794/ijme.92.res

Verblanken, B. and Holland, R.W. (2002).Motivated Decision-Making: Effects of Activation and Self-Centrality of Values on Choices and Behavior. Journal of Personality and Social Psychology, 82, 434-447. https://doi.org/10.1037//0022-3514.82.3.434

Weber, J. and Green, S. (1991).Principled Moral Reasoning: Is It a Viable Approach to Promote Ethical Integrity?. Journal of Business Ethics, 10, 325-333. https://doi.org/10.1007/bf00383233

Weinberg, R.S. (1996). Goal Setting in Sport and Exercise: Research to Practice. In J. L. Van Raalte and B.W. Brewer (Eds.). Exploring Sport and Exercise Psychology, (pp.3-24), Washington, D.C.: American Psychological Association. https://doi.org/10.1037/10186-001

Yukl, G. (2010). Leadership in Organizations, $\left(7^{\text {th }}\right.$ ed.), Upper Saddle River, NJ: Prentice Hall. https://doi.org/10.2307/257314 


\section{Appendix A}

\section{Integrating Value Congruence}

\section{Topical Quotes: Samples}

- "Their education must help them to understand their reality and, if it is fiction, like all fiction, it must reveal its moral content" -- P. Anthony, Researcher and Author

- "At this moment, American's highest economic need is higher ethical standards - standards enforce by strict laws and upheld by responsible business leaders." - George w. Bus, former President of the United State

- "Personal leadership is the process of keeping your vision and values before you and aligning your life to be congruent with them." -- Stephen Covey, Consultant and Author

- "It's not hard to make decisions when you know what your values are." - Roy Disney, Film Writer and Producer

- "Values provide perspective in the best of times and the worst." - Charles Garfield, Motivational Speaker

- "Things only have the value that we give them." - Moliere, Actor and Playwright

- "The individual increasingly comes to know who he is through the stand he takes when he expresses his ideas, values, beliefs, and convictions, and through the declaration and ownership of his feelings." - Clark Moustakas, leading expert on humanistic and clinical psychology.

- "Know thyself." - Plato, Philosopher

- "You must look within for value, but look beyond for perspective," - Denis Waitley, Author, Lecturer, and Productivity Consultant

- "There's a difference between interest and commitment. When you're interested in doing something, you do it only when circumstance permit. When you're committed to something, you accept no excuses, only results." -- Source Unknown. 


\section{Appendix B1 \\ Integrating Value Congruence}

\section{Values Defined: Mix and Match Activity - Part I}

The term "values" has been defined in many ways including: what is right (vs. wrong), good (vs. not good), or desirable (vs. not desirable), and what people would like to achieve in their lives.

\section{Instructions:}

- Different values appear in column A which reflect potential life goals

- Incorrect definitions for these values appear in column B

- Place the correct definition in column $\mathrm{C}$ for the Value noted in column A

- On line D, identify and define additional values that you believe are important and should be added to this list of values.

A

\begin{tabular}{|c|c|c|}
\hline Value & Incorrect Definition & Correct Definition \\
\hline A sense of Accomplishment & Self-sufficient; self-reliant & \\
\hline A world of Beauty & Affectionate; tender & \\
\hline A Comfortable life & Mature understanding of life & \\
\hline Equality & Competent; effective & \\
\hline Excitement & Saved; eternal life & \\
\hline Family security & Freedom from inner conflict & \\
\hline Freedom & Leisurely, enjoyable life & \\
\hline Happiness & Dutifulness & \\
\hline Inner harmony & Free of war or conflict & \\
\hline Mature love & Reliable; dependable & \\
\hline National security & Sexual and spiritual intimacy & \\
\hline A world of Peace & Sincerity; truthfulness & \\
\hline Pleasure & Free choice & \\
\hline Salvation & Self-disciplined & \\
\hline Self-respect & Standing up for one's beliefs & \\
\hline Social recognition & Brotherhood; equal opportunity & \\
\hline True friendship & Lightheartedness; joyful & \\
\hline Wisdom & Admiration; respect & \\
\hline D. Values added by student & & \\
\hline
\end{tabular}


Appendix B2

Integration Value Congruence

\section{Values Defined: Mix and Match Activity - Activity Answers}

$\mathbf{A}$

B

C

\begin{tabular}{|l|l|l|}
\hline \multicolumn{1}{|c|}{ Value } & \multicolumn{1}{c|}{ Incorrect Definition } & \multicolumn{1}{c|}{ Correct Definition } \\
\hline A sense of Accomplishment & Stimulation & $\begin{array}{l}\text { A sense that you are making a lasting } \\
\text { contribution }\end{array}$ \\
\hline A world of Beauty & Saved; an eternal life & Beauty of nature and/or the arts \\
\hline A Comfortable life & Taking care of loved ones & Prosperity \\
\hline Equality & Free of war and conflict & Brotherhood; equal opportunity \\
\hline Excitement & Close companionship & Stimulation \\
\hline Family Security & Beauty of nature and/or the arts & Taking care of loved ones \\
\hline Freedom & Freedom from inner conflict & Free choice \\
\hline Happiness & Protection from attack & Contentedness \\
\hline Inner harmony & Self-esteem & Freedom from inner conflict \\
\hline Mature love & Leisure; an enjoyable life & Sexual and spiritual intimacy \\
\hline National security & Mature understanding of life & Protection from attack \\
\hline A world of Peace & $\begin{array}{l}\text { A sense that you are making a lasting } \\
\text { contribution }\end{array}$ & Free of war and conflict \\
\hline Pleasure & Admiration; respect & Leisure; an enjoyable life \\
\hline Salvation & Sexual and spiritual intimacy & Saved; an eternal life \\
\hline Self-Respect & Prosperity & Self-esteem \\
\hline Social Recognition & Free choice & Admiration; respect \\
\hline True friendship & Contentedness & Close companionship \\
\hline Wisdom & Brotherhood; equal opportunity & Mature understanding of life \\
\hline D. Values added by student & & \\
\hline Source: Rokach, & & Fing \\
\hline
\end{tabular}

Source: Rokeach, M. (1973). The Nature of Human Values, New York: Free Press. 


\section{Appendix B3}

Integration Value Congruence

\section{Values Defined: Values Defined: Mix and Match Part II}

The term "values" has been defined in many ways including: what is right (vs. wrong), good (vs. not good), or desirable (vs. not desirable), and the means for achieving life goals.

\section{Instructions:}

- Different values appear in column A which reflect the means to attain one's life goals.

- Incorrect definitions for these values appear in column B

- Place the correct definition in column $\mathrm{C}$ for the Value noted in column A

- On line D, identify and define additional values that you believe are important and should be added to this list of values.

A

\begin{tabular}{|l|l|l|}
\hline \multicolumn{1}{|c|}{ Value } & \multicolumn{1}{c|}{ Incorrect Definition } & Correct Definition \\
\hline Ambitiousness & Taking care of loved ones & \\
\hline Broad-mindedness & Protection from attack & \\
\hline Capable & Close companionship & \\
\hline Cheerfulness & Prosperity & \\
\hline Clean & Open-mindedness & \\
\hline Courageousness & Self-esteem & \\
\hline Forgiveness & Courteousness; well-mannered & \\
\hline Helpfulness & Hardworking & \\
\hline Honesty & Creativity; daringness & \\
\hline Imagination & Contentedness & \\
\hline Independence & A sense of making a lasting contribution & \\
\hline Intellectual & Working for the welfare of others & \\
\hline Logical & Intelligent; reflective & \\
\hline Loving & Beauty of nature and/or the arts & \\
\hline Obedience & Neat and tidy & \\
\hline Polite & Rational; consistent & \\
\hline Salvation & Self-disciplined & \\
\hline Self-controlled & Willing to pardon others & \\
\hline D. Values added by student & & \\
\hline
\end{tabular}




\section{Appendix B4}

Integration Value Congruence

Values Defined: Mix and Match Part II - Activity Answers

A

B

C

\begin{tabular}{|l|l|l|}
\hline \multicolumn{1}{|c|}{ Value } & \multicolumn{1}{c|}{ Incorrect Definition } & \multicolumn{1}{c|}{ Correct Definition } \\
\hline Ambitiousness & Neat and tidy & Hardworking \\
\hline Broad-mindedness & Willing to pardon others & Open-mindedness \\
\hline Capable & Self-sufficiency; self-reliance & Competent; effective \\
\hline Cheerfulness & Affectionate; tender & Lightheartedness; joyful \\
\hline Clean & Intelligent; reflective & Neat and tidy \\
\hline Courageousness & Lightheartedness; joyful & Standing up for one's beliefs \\
\hline Forgiveness & Dutifulness & Willing to pardon others \\
\hline Helpfulness & Open-mindedness & Working for the welfare of others \\
\hline Honesty & Courteous; well-mannered & Sincerity; truthfulness \\
\hline Imagination & Working for the welfare of others & Creativity; daringness \\
\hline Independence & Self-disciplined & Self-sufficiency; self-reliance \\
\hline Intellectual & Competent; effective & Intelligent; reflective \\
\hline Logical & Reliable; dependable & Rational; consistent \\
\hline Loving & Sincerity; truthfulness & Affectionate; tender \\
\hline Obedience & Rational; consistent & Dutifulness \\
\hline Polite & Creativity; daringness & Courteous; well-mannered \\
\hline Responsible & Hardworking & Reliable; dependable \\
\hline Self-controlled & Stand up for one's beliefs & Self-disciplined \\
\hline & & \\
\hline
\end{tabular}

Source: Rokeach, M. (1973). The Nature of Human Values, New York: Free Press. 


\section{Individual Values Explored}

\section{Instructions: Complete Parts I and II of this activity.}

- Part I: In column B, list each of your top 3 "life goal" values. For each value, describe why this value is important to you in column $\mathrm{B}$.

- Part II: In column A, list each of the top 3 values which reflect the means to attain your goals. For each value, describe why this value is important to you in column B.

Values (A)

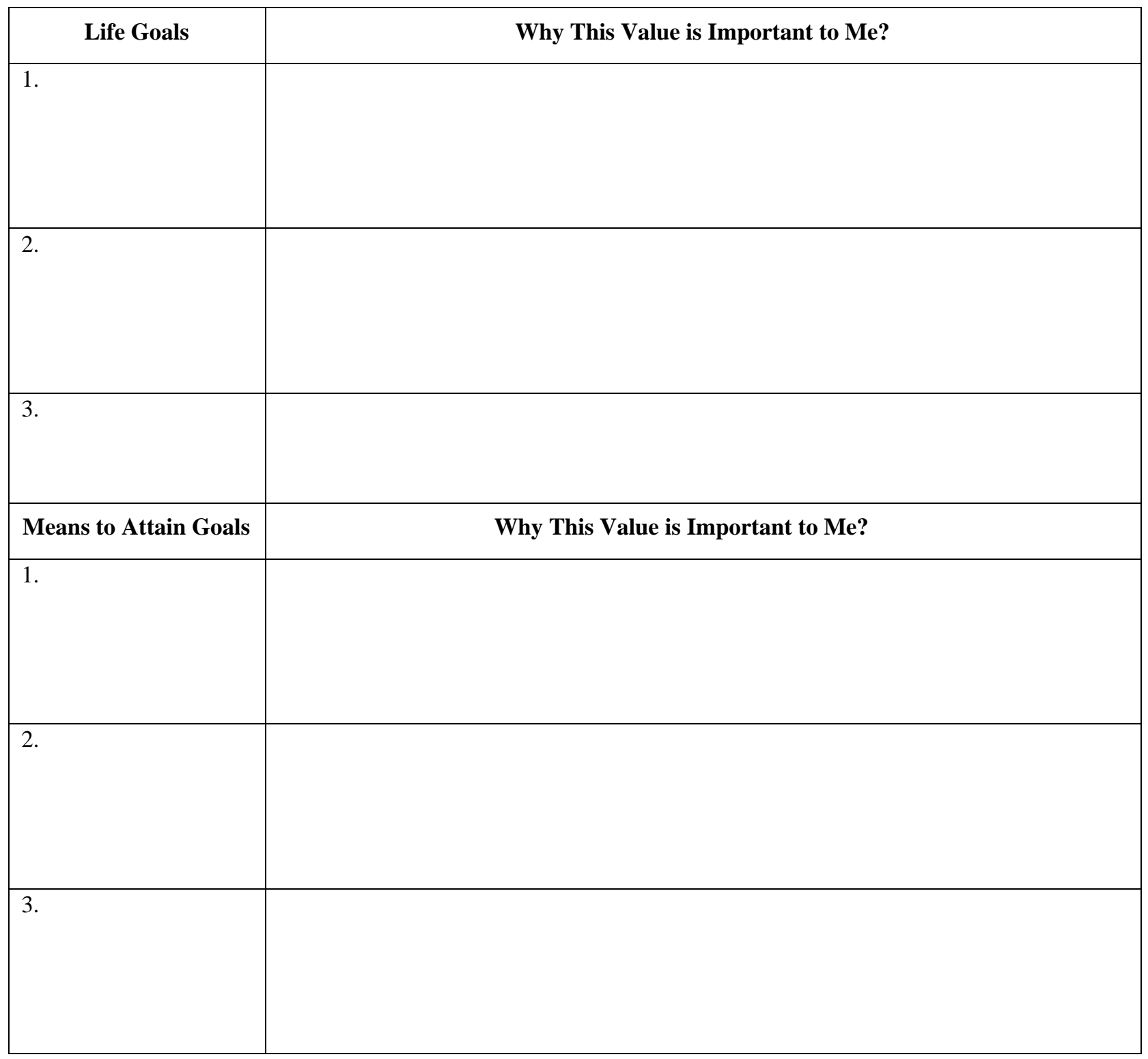




\section{In Search of Organizational Values}

\section{General Ouestions}

- What is the organization's mission? Does this mission promote specific organizational values?

- How does the organization communicate or promote its values as an integral part of its identity and/or within everyday work life?

- What human resource policies, programs and procedures are in effect? What does this material suggest about the organization's values?

- What competencies does the organization promote for on-the-job success? How do these competencies relate to organizational values?

- What is the management style of the organizational leadership and how is management leadership associated with organizational values?

- What important decisions has the organization made in the in the last few years and what values drove those decisions?

- What does internal organizational information (Internet, promotional literature, recruitment literature, advertisements, etc.) indicate about the organization, its industry and organizational values?

- What does external information indicate about the organization, its industry, and organizational values? (Examples: articles, blogs, other media, social websites, trade associations, government agencies, current and former employees, other?) 
Appendix E

Integration Value Congruence

\section{In Search of an Organizational and Personal Values Connection}

\section{Part I: Values that are Life Goals}

Identify behaviors or actions by an organization or its members that demonstrate only the top 3 values you selected. Sample questions to assist in this analysis are shown, by value, below. Other questions may be added.

\begin{tabular}{|c|c|}
\hline $\begin{array}{c}\text { In Search of Organization Values Sample } \\
\text { Questions }\end{array}$ & $\begin{array}{c}\text { Behaviors or Actions Demonstrated } \\
\text { by the Organization }\end{array}$ \\
\hline \multicolumn{2}{|l|}{$\begin{array}{l}\text { A Sense of Accomplishment: What is the organization's reputation? How } \\
\text { do employees or the organization earn rewards for? Do organizational } \\
\text { communications or actions acknowledge employee successes? Do projects } \\
\text { seem to conclude on a timely basis? Does the organization identify clear } \\
\text { roles for employees (e.g. job descriptions, performance reviews, etc.)? } \\
\text { How do employees know what success looks like in a job? Are employees } \\
\text { held personally accountable for their actions? }\end{array}$} \\
\hline \multicolumn{2}{|l|}{$\begin{array}{l}\text { A World of Beauty: Does the organization support specific environmental } \\
\text { causes, art, research in support of beauty? What do organizational locations } \\
\text { physically look like? What do the employees look like? }\end{array}$} \\
\hline \multicolumn{2}{|l|}{$\begin{array}{l}\text { A Comfortable Life: What is the organization's view about compensation, } \\
\text { benefits and perks? What other financial or emotional (e.g. entertainment, } \\
\text { education, travel, etc.) benefits does this organization provide? Does the } \\
\text { organization provide family benefits? }\end{array}$} \\
\hline \multicolumn{2}{|l|}{$\begin{array}{l}\text { Equality: Are programs, procedures and policies applied fairly? Does the } \\
\text { organization promote equality in is human resource policies, interactions with } \\
\text { customers? How does the organizational promote diversity? Is there a } \\
\text { successful ethics program? Are there equality or ethics issues or lawsuits? }\end{array}$} \\
\hline \multicolumn{2}{|l|}{$\begin{array}{l}\text { Excitement: Does the organization support things that are new, creative, and } \\
\text { innovative? Are jobs routine? Is the company changing and how? What is } \\
\text { the impact of globalization, new technology, industry growth, management } \\
\text { changes, mergers and acquisitions, etc? Are there rumors about the } \\
\text { organization and why? What learning and developing opportunities are } \\
\text { available? }\end{array}$} \\
\hline \multicolumn{2}{|l|}{$\begin{array}{l}\text { Family Security: Does the organization promote work/life balance } \\
\text { concepts? Is there a strong total compensation program including vacation } \\
\text { time? Can employees and their families live in a safe neighborhood? Does } \\
\text { the organization promote educational programs or other benefits for the } \\
\text { family? Do organizational restructurings put jobs or careers at risk? }\end{array}$} \\
\hline $\begin{array}{l}\text { Freedom: What is the structure of the organization (e.g. bureaucratic or } \\
\text { networked?) Is the structure, chain of command, culture, etc., rigid, or } \\
\text { flexible? Does the organization promote adaptability and change? If so, } \\
\text { how? }\end{array}$ & \\
\hline
\end{tabular}




\section{Integration Value Congruence}

Happiness: What is the job satisfaction level of employees and how does the organization or employees know this? What is the level of job turnover? Are employees smiling?

Inner Harmony: Does the organization promote work-life balance? Are there ways to support personal development? Does the organization offer sabbaticals? Does the organization provide stress reduction classes or gym membership? Are there classes or meetings relating to peace of mind or inner harmony? (e.g. yoga, etc.).

Mature Love: Does the organization support different sexual and/or spiritual orientations (e.g. clubs, counseling, speakers, association sponsorships, etc.)?

National Security: What is the relationship between this organization and governments? Is the organization working with some form of military operation? If so, how?

A World of Peace: Does the organization support collaboration and teamwork or competition? Does the organization support global relationships with organizations, governments and/or employees? Are there programs on conflict resolution, negotiation, etc.?

Pleasure: Is the culture 9-5 or are employees expected to work 12 hours a day? Does the organization promote work-life balance? What is the vacation policy? Are family and friend events sponsored? Are sports or other fun activities sponsored?

Salvation: Do organizational values support a spiritual journey to salvation? If so, how? How are spiritual values incorporated within organizational work? Does the organization support personal reflection?

Self-Respect: How are employees motivated at work? How are employees recognized on-the-job? Is there a job promotion program? Are employees encouraged to grow and learn on the job or in the organization?

Social Recognition: How does the organization communicate employee success? Does the organization promote recognition awards or programs? And to whom? Internal organizational members? The industry? Family of the organization? The media?

True Friendship: What is the organizational culture like? Does the organization support clubs, teams, associations, blogs, groups, activities, etc. where employees can interact? Can employees easily interact in lunch rooms, break rooms, etc.? What is the level of employee turnover?

Wisdom: Does the organization promote planned or unplanned changes at work? Is the organization socially responsible? Does the organization support the environment and other worldly issues?

Values Added by the Student: 


\section{Integration Value Congruence}

\section{Part II: Values to Achieve Goals}

Identify behaviors or actions by an organization or its members that demonstrate only the top 3 values you selected. Sample questions to assist in this analysis are shown, by value, below. Other questions may be added.

\begin{tabular}{|c|c|}
\hline In Search of Organization Values Sample Questions & $\begin{array}{l}\text { Behaviors or Actions } \\
\text { Demonstrated by the } \\
\text { Organization }\end{array}$ \\
\hline \multicolumn{2}{|l|}{$\begin{array}{l}\text { Ambitiousness: Is the organizational culture collaborative or competitive? How } \\
\text { is job and organizational performance evaluated? Why are employees promoted } \\
\text { within the organization? Do employees work } 24 / 7 \text { ? Is a lot of overtime work } \\
\text { encouraged? }\end{array}$} \\
\hline \multicolumn{2}{|l|}{$\begin{array}{l}\text { Broadmindedness: Is the organization a trendsetter or a follower in its activities? } \\
\text { Are they the first or last to support a new idea or approach? Is risk taking } \\
\text { encouraged? }\end{array}$} \\
\hline \multicolumn{2}{|l|}{$\begin{array}{l}\text { Capable: Does the organization and its employees 'make things happen?' Is } \\
\text { there a "beginning," "middle" and "end" to work tasks? Does the organization } \\
\text { demonstrate close supervision of employees or do employees work } \\
\text { independently of supervision? }\end{array}$} \\
\hline \multicolumn{2}{|l|}{$\begin{array}{l}\text { Cheerfulness: Is there celebration at work? Are holidays and special events } \\
\text { important? How is humor infused with the culture? Is work taken very seriously? }\end{array}$} \\
\hline \multicolumn{2}{|l|}{$\begin{array}{l}\text { Clean: How organized is the organization? Is planning and control } \\
\text { demonstrated? Is good attendance and punctuality promoted? Are the offices } \\
\text { neat and clean? Are there recycling programs? }\end{array}$} \\
\hline \multicolumn{2}{|l|}{$\begin{array}{l}\text { Courageousness: Is risk taking supported? Is there a work environment of } \\
\text { openness, trust and challenge? How do you know? Does the organization use } \\
\text { change pilots to test out new ideas or approaches? Does the organization } \\
\text { promote new or different causes? }\end{array}$} \\
\hline \multicolumn{2}{|l|}{$\begin{array}{l}\text { Forgiveness: How are people treated when an employee does not perform well } \\
\text { or if a project or task is unsuccessful? What is the level of employee turnover } \\
\text { and why? }\end{array}$} \\
\hline \multicolumn{2}{|l|}{$\begin{array}{l}\text { Helpfulness: Are employee 'volunteer' programs promoted by the } \\
\text { organization? Is social entrepreneurship supported by the organization? Is } \\
\text { corporate philanthropy and citizenship supported? }\end{array}$} \\
\hline \multicolumn{2}{|l|}{$\begin{array}{l}\text { Honesty: Do organizational policies promote lawful compliance? Does the } \\
\text { organization conduct business in a lawful manner? Does the organization } \\
\text { promulgate false or misleading information? Are organizational products and } \\
\text { services of the highest quality? Does the organization stand behind its products } \\
\text { and services? }\end{array}$} \\
\hline $\begin{array}{l}\text { Imagination: Is the industry/organization changing or do they need to change? } \\
\text { How does the organization reward employees for creativity and/or daringness? } \\
\text { Are money, time and effort put into creation of new ideas? }\end{array}$ & \\
\hline
\end{tabular}




\section{Integration Value Congruence}

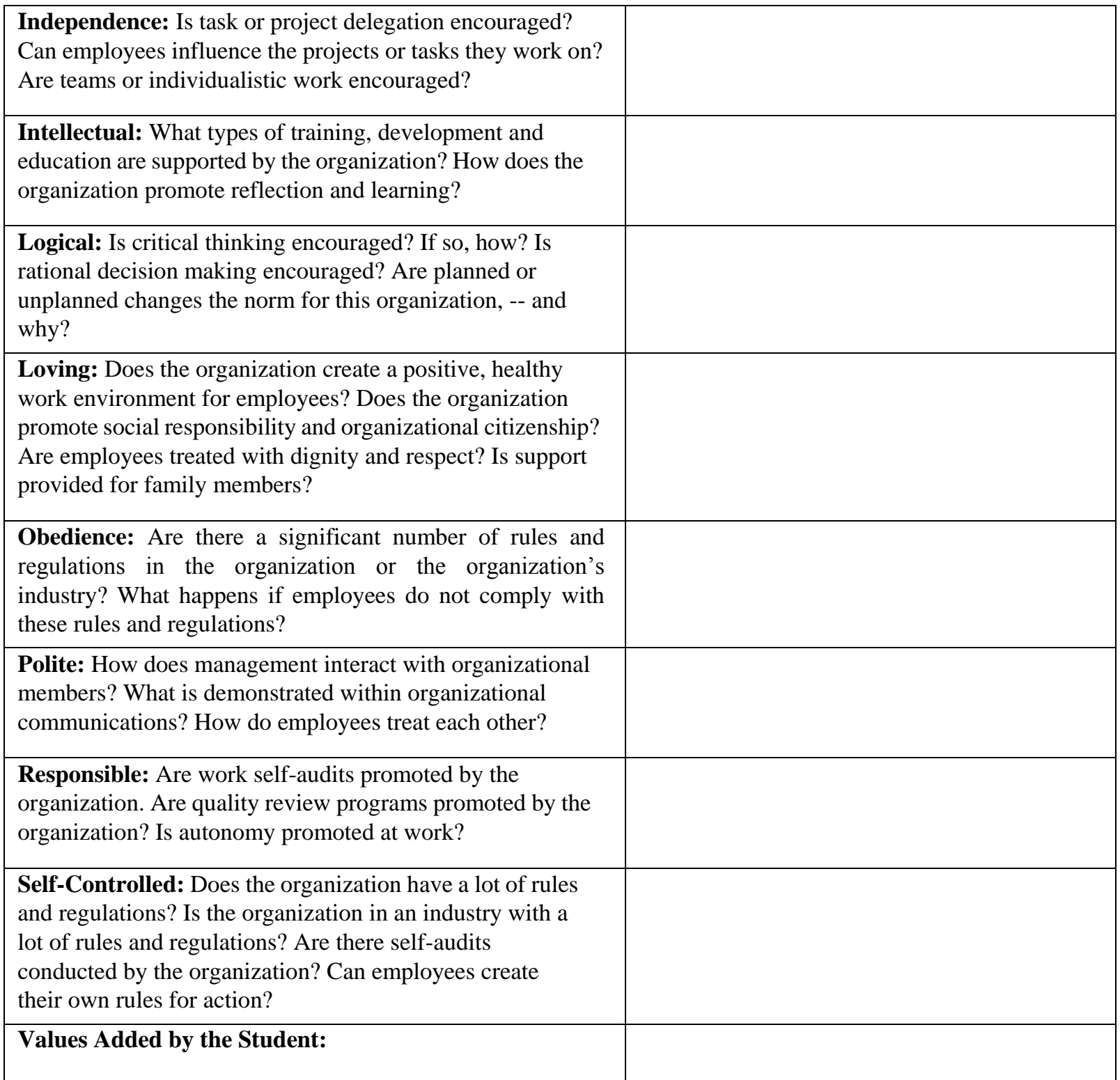

Part III. Complete the following: To what degree is there value congruence or value incongruence between this organization and your personal values? Clarify your response. (Use the back side of this form if additional space is needed.) 


\section{Appendix F \\ Integrating Value Congruence \\ Research and Reflection Paper \\ Connecting Value Congruence, Ethics and Your Employment Goal}

\section{Introduction}

A value refers to the worth, importance, or usefulness of something to somebody. Values are anything we hold in high esteem, and they can be people, things, or even ideas. Personal values are your convictions regarding what we believe are important and desirable.

\section{Instructions for Your Individual Research and Reflection Paper}

You are asked to write a research and reflection paper that explores the concepts of value congruence, ethics and your post-graduation employment goal. Please follow these instructions:

-Read Activities \#1-\#7 before starting this project for greater understanding of the assignment. Use Activities \#1-\#7 to support your work.

-The paper should be a minimum of 5 pages in length, excluding references.

-A minimum of five peer-reviewed sources should be cited and referenced for the basic paper.

-The paper should be written in accordance with APA formatting standards.

-Read the Grading Guidelines for this Activity before starting the project.

-Address the following items in your paper:

- Define value congruence and value incongruence. Explain whether value congruence is important at work and why.

- Describe your personal values, indicating why these values are important to you.

- Identify an organization with values that align with your personal values which could serve as a target organization for future employment after graduating from college. Describe how the organization you selected promotes organizational values that align with your personal values. For example, what behaviors or actions are enacted by the organization or the organizational members which lead you to believe that the organization's values align with your personal values?

- Research and summarize five peer-reviewed articles that discuss the relationship between value congruence and ethics. As part of this process.

- Describe the relationship between value congruence and ethics.

- Describe the value of working for an organization with values that align with your personal values relative to ethics.

- Indicate whether the organization you selected (in step \#2 above) could support your ethical well- being at work and why.

\section{Optional Extra Credit Assignment}

Since you are (hopefully) graduating within the next year or two, each of you have probably identified employment fields or disciplines (accounting, finance, IT, human resources, marketing, sales, etc.) that you wish to enter once you graduate from college. The purpose of this optional extra credit assignment is for students to explore their values related to success in the fields or disciplines in which students wish to work. As part of this process:

- Identify the employment field or discipline that you would like to enter once you graduate. If you are not sure of your exact field, use your course concentration for your degree (i.e., a concentration in human resources, finance, marketing, etc. for purposes of this assignment.) 


\section{Integrating Value Congruence}

- Research and identify the professional values that support success in the field or discipline where you plan to work.

○ Identify the relationship between value congruence and ethics in this field or discipline.

- Explain if and how the organization that you selected in step \#2 above supports value congruence and ethics in your chosen field.

The optional extra credit assignment, if completed (shown below), should add about one additional page in length, excluding references.

A minimum of two credible sources should support the optional extra credit assignment.

\section{Grading Guidelines}

It is helpful to understand how your work will be assessed before your start the project. With this information in mind, you can complete the project to your best advantage. The following guidelines will be used to evaluate your work.

\section{Grading Guidelines - Research and Reflection Paper}

\begin{tabular}{l}
\hline CONTENT \\
.Define value congruence and value incongruence. Explain (and clarify) whether \\
value congruence is important at work. \\
2. Describe your personal values, indicating why these values are important to you. \\
3.Identify an organization with values that align with your personal values which could \\
serve as a target organization for future employment after graduation. Describe how \\
the organization you selected promotes values that align with your personal values.
\end{tabular}

1.Research and summarize five peer-reviewed articles that discuss the relationship between value congruence and ethics. As part of this process:

- Describe the relationship between value congruence and ethics.

- Describe the value of working for an organization with values that align with your personal values relative to ethics.

- Indicate (and clarify) whether the organization you selected (in step \#2 above) supports your ethical well-being at work..

\section{Optional Extra Credit Assignment}

- Identify the employment field or discipline that you would like to enter once you graduate.

- Research and identify the professional values that support success in the field or discipline where you plan to work.

- Identify the relationship between value congruence and ethics in this field or discipline.

- Explain (and clarify) if and how the organization that you selected (in step \#3 above) 


\section{Integrating Value Congruence}

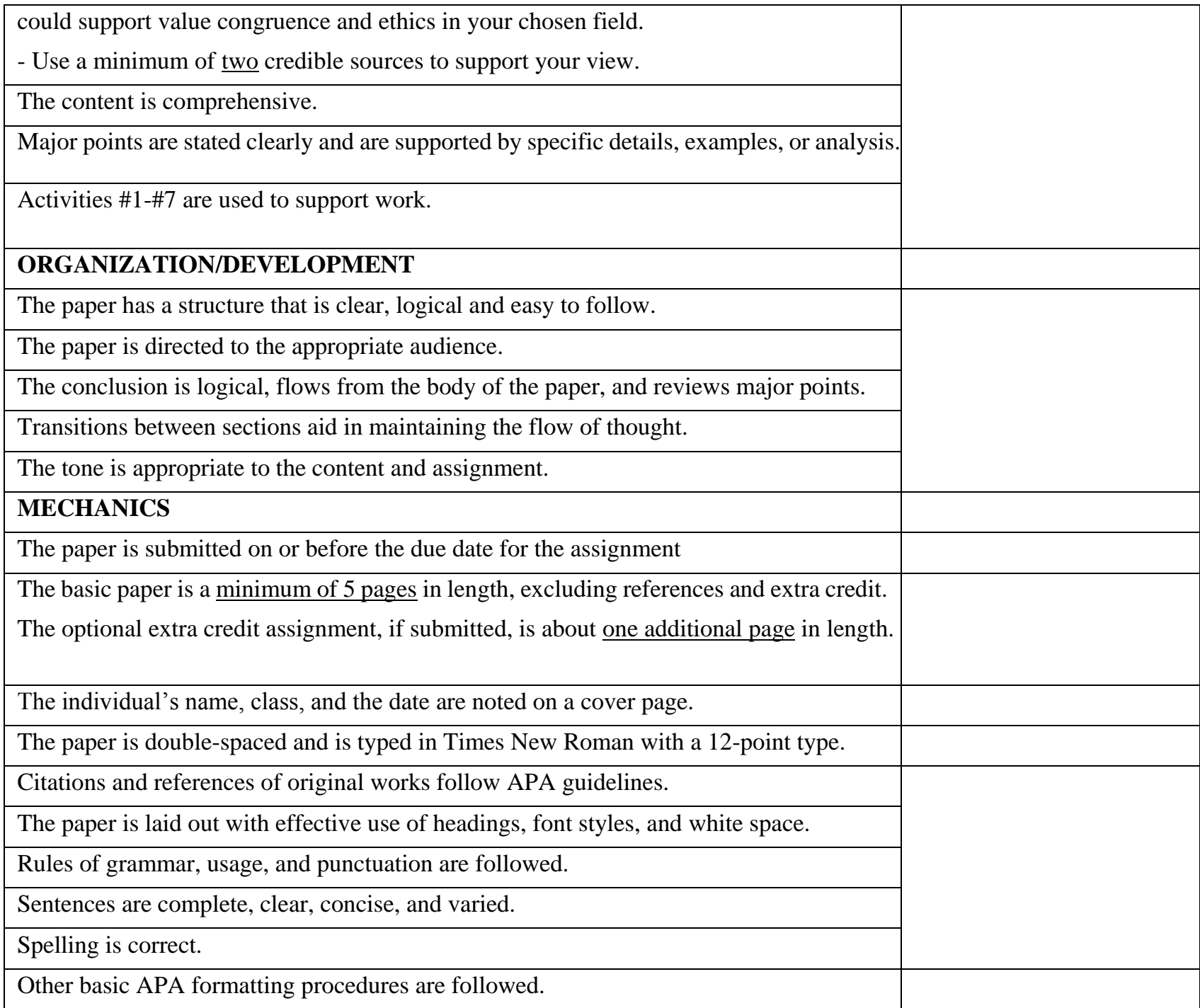

Points Earned for this Assignment (To be completed by the instructor):

Additional Comments by Instructor (To be completed by the instructor, as necessary): 


\section{Appendix G \\ Integrating Value Congruence}

\section{Research and Reflection Paper: \\ ePortfolio Version Connecting Value Congruence, Ethics and Your Employment Goal}

Introduction: A value refers to the worth, importance, or usefulness of something to somebody. Values are anything we hold in high esteem. Your personal values are your convictions regarding what you believe are important and desirable.

Instructions: You are asked to research and reflect upon the concepts of value congruence, and ethics relative to your post-graduation employment goal. Use Activities \#1-\#7 to support your work. Please address each of the following questions as follows.

Page 1: Start the assignment by completing a section entitled, "About Me." Here you will share some basic information to introduce yourself..

Page 2: (a) Define value congruence and value incongruence. Explain whether value congruence is important at work and why, (b) Describe your personal values, indicating why these values are important to you, (c) Identify an organization with values in alignment with your top personal values which can serve as a target organization for future employment after graduating from college. Describe how the organization you selected promotes organizational values that align with your personal values. For example, what behaviors or actions are enacted by the organization or the organizational members which lead you to believe that the organization's values align with your values?

Page 3: Research and summarize five peer-reviewed articles that discuss the relationship between value congruence and ethics. As part of this process: (a) describe the relationship between value congruence and ethics,

(b) describe the value of working for an organization with values that align with your personal values relative to ethics, and (c) indicate whether the organization you selected could support your ethical well-being at work and why.

Page 4: Reflections. Answer these questions after you complete pages 1-3: (a) what did you know about value congruence before the semester? (b) what did you learn about values, value congruence, and ethics when completing this exercise?

Page 5: Optional Extra Credit Assignment: Since you are (hopefully) graduating from college soon, you have probably identified an employment field or discipline (accounting, finance, IT, human resources, marketing, sales, etc.) that you wish to enter after graduation. The purpose of this optional extra credit assignment is for students to explore their values related to success in the fields or disciplines in which students wish to work. As part of this process: (a) identify the employment field or discipline that you would like to enter once you graduate. If you are not sure of your exact field, use your course concentration for your degree (i.e., a concentration in human resources, finance, marketing, etc. for purposes of this assignment), (b) research the professional values that support success in the field or discipline where you plan to work, (c) identify the relationship between value congruence and ethics in this field or discipline, (d) explain if and how the organization that you selected could support value congruence and ethics in your chosen field? A minimum of two credible sources should be used to support your response. 